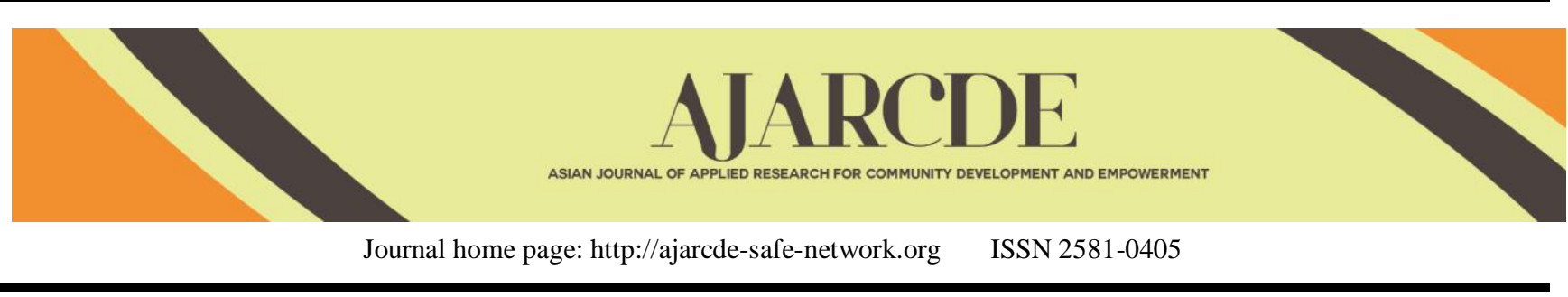

\title{
Response of Soybean (Glycine Max (L.) Merrill) to Organic and Inorganic Fertilizers
}

Jonie C. Simbulan and Norman G. De Jesus*

Alternative Low Input Agriculture System (ALIAS) R\&DE Center. Pampanga State Agricultural University (PSAU), Magalang, Pampanga.

\section{ARTICLE INFO}

Article History:

Received: 07 October 2019

Final Revision: 12 January 2020

Accepted: 23 February 2020

Online Publication: 07 March 20

\section{KEYWORDS}

organic fertilizer, inorganic fertilizer, Soybean (Glycine Max (L.) Merrill, growth performance

\section{CORRESPONDING AUTHOR}

*E-mail: normandejesus2005@yahoo.com.ph

\section{A B S T R A C T}

The effects of organic and inorganic fertilizers on the growth and yield performance of soybean was evaluated at ALIAS R \& DE Center, Pampanga State Agricultural University (PSAU), PAC, Magalang, Pampanga. It was laid out in the field according to the procedures of randomized complete block design (RCBD) with three replications. The treatments tested were T1 - No fertilizer application, T2 - 500 kg/ha of Power Organic, T3 $-21.74 \mathrm{~kg} / \mathrm{ha}$ of Urea and $150 \mathrm{~kg} / \mathrm{ha}$ of Super Phosphate, T4 $-250 \mathrm{~kg} / \mathrm{ha}$ of Power Organic $+10.87 \mathrm{~kg} / \mathrm{ha}$ of Urea and $75 \mathrm{~kg} / \mathrm{ha}$ of Super Phosphate, $\mathrm{T} 5-375 \mathrm{~kg} / \mathrm{ha}$ of Power Organic $+5.44 \mathrm{~kg} / \mathrm{ha}$ of Urea and 37.5/ha of Super Phosphate, T6 - $125 \mathrm{~kg} / \mathrm{ha}$ of Power Organic $+16.31 \mathrm{~kg} / \mathrm{ha}$ of Urea and $112 \mathrm{~kg} / \mathrm{ha}$ of Super Phosphate. Results revealed that all organic and inorganic fertilizers applied crops were significantly different in terms of days to flowering, plant height at flowering, length of pods, weight of 100 seeds and computed seed yield per hectare. Cost and return analysis reveals that the highest net income and return of investment was derived from the combination of $50 \%$ organic and $50 \%$ inorganic fertilizer. Conjunctive use of organic and inorganic fertilizer, that is, 50 $\%$ recommended rate of organic fertilizer (Power organic) along with $50 \%$ recommended rate of inorganic fertilizer (Urea and Super Phosphate) can enhance the growth and yield performance of soybean and can help the farmer to increase their production with higher net income. Results of the study revealed that all the treatments applied with organic and inorganic fertilizers were significantly different in terms of days to flowering, plant height at maturity, length of pods, weight of 100 seeds and computed yield per hectare. On the contrary, insignificant findings was observed among the treatments with regards to days to maturity, plant height at 60 days and maturity, number of pods per plant, number of seeds per pod and shelling percentage.

\section{INTRODUCTION}

\subsection{Research Background}

Soybeans (Glycine max L. Merr.) are annual flowering crop which are members of Leguminosae or Fabaceae family [1]. It is considered as one of the most important crops in the world that have the potential to provide the world's increasing demand for food and forage. Soybean is one of the cheapest but richest source of protein that became part of the diets of many people and animals around the world [2]. In the Philippines, soybean and its components are widely utilized for food and feed industries. As human food, soybean is consumed in the form of soymilk and soybean curd (taho and tokwa). Soybean meal is a by-product of oil extraction which serve as the chief source of protein for feeds by the livestock industry. This legume is also the main ingredient for making soy sauce (toyo) using the acid hydrolysis method [3].

Plant nutrients are beneficial for the production of crops and healthy food for the world's increasing population. Therefore, plant nutrients are important component of sustainable agriculture. Increased crop production largely relies on the type of fertilizers being used to supplement essential nutrients for plants. The nature and the characteristics of nutrient release of chemical and organic fertilizer are different, and each type of fertilizer has its benefits and disadvantages with respect to crop growth and fertility of soil [4].

The integrated nutrient management is an alternative and is characterized by reduced input of synthetic fertilizers and combined usage of chemical fertilizers with organic materials such as animal manures, crop residues, green manure and composts. Production systems that rely on organic inputs as plant nutrient sources have different dynamics of nutrient availability from those involving the use of chemical fertilizers. For sustainable crop production, integrated use of chemical and organic fertilizer has proved to be highly beneficial [5]. The integration of chemical and organic fertilizer must be managed well to guarantee both enhanced and safe environment. As being said earlier their integration improves nutrient availability, optimizes the soil environment and improves crop productivity [4]. Therefore, a balanced strategy that combines organic and inorganic inputs have been developed and evaluated in this study. 


\subsection{Literature Review}

Farmers are more interested in using synthetic fertilizer for their crops for ease of handling, because of this the use of organic fertilizer is not popular. The effect of synthetic fertilizer is not quite well because it has led to problems in degradation of soil which is alarming on crop production. Therefore, a balanced fertilization is needed by farmer in crop production. Combined application of organic and inorganic fertilizer may lessen the use of chemical fertilizer, which means that the cost of production may be reduced. Ref. [6] stated that conjunctive applications of chemical fertilizers and organics may lessen the imbalanced nutrients in soil and may boost the crop production and eventually, there will be sustainable production and pollution-free environment. According to Ref. [7], integrated use of chemical fertilizer with cowdung, biofertilizer and poultry manure can increase the yield and yield contributing characters such as 100 seed weight, number of pods, grain yield, straw yield and biological yield. Their combination will eventually result to the increase of soybean production.

Ref. [8] have observed that chemical fertilizer along with organic fertilizer (manure) application significantly improved the stover and seed yield of soybean over the control. Based on their experiment, the application of FYM @ 4 tons per hectare together with the recommended rate of NPK fertilizer significantly improve the seed yield of soybean by 14 percent over NPK and 51.8 percent over the non-application of fertilizer (control). According to Ref. [9], the recommended dose of NPK fertilizers with Organic Fertilizer (FYM) recorded significantly higher seed yield (22.35 q ha-1) and yield components.

Yamika and Ikawati [10] have discovered in their study that the combination of organic and inorganic fertilizer have significant effect on growth and yield production of soybean (number of flowers, number of pods, weight of 100 grains and yield ha-1). The combination of inorganic and organic fertilizer at a dose of $225 \mathrm{~kg} \mathrm{ha}^{-1}$ and $1 \mathrm{t} \mathrm{ha}^{-1}$ respectively obtained the highest yield production of soybean which is 3.51 tons ha- 1 . The combination of organic and inorganic fertilizer have for up to also increased 41 percent yield production of soybean compared to organic fertilizer alone at dose $75 \mathrm{~kg} \mathrm{ha}^{-1}$. Aside from increased yield production of soybean, the combination also increased $\mathrm{C}$ organic of soil $26.4 \%$ as compared with inorganic fertilizer at dose $75 \mathrm{~kg} \mathrm{ha}^{-1}$ without adding organic fertilizer. Ref. [11] discovered that the soil physical properties were enhanced because of application of chemical fertilizer in combination with organics compare to chemical fertilizers only. The combined use of fertilizers was helpful to improve soil properties by increasing labile soil C fractions and maintained the crop yields. Ref. [13] have testified that combined application of inorganic and organic fertilizers helped in increasing the availability of nutrients and improves major physical and chemical characteristics of the soil. They conclude that the application of $50 \%$ fertilizers from inorganic sources and $50 \%$ from organic is the best combination and reported by many scientists for soil properties improvement.

\subsection{Research Objective}

The general objective of the study was to determine the effects of organic and inorganic fertilizers on the growth and yield performance of soybean.

\section{MATERIALS AND METHODS}

\subsection{Preparation of substrates}

Cl Soy1 is the experimental crop that was used in the study. This is a variety of soybean that matures from 80 to 90 days after planting. CL Soy1 are characterized by brown seed color, small seed size, it can contain 2-4 seeds per pod and has a medium short plant height.The study was arranged according to the procedures of Randomized Complete Block Design with three replications. The treatments are as follows: T1 - No fertilizer application, T2 - Recommended rate of POWER Organic, T3 - Recommended rate of Urea and Super Phosphate, and T4 - 50 \% RR of POWER Organic $+50 \%$ RR of Urea and Super Phosphate.

Data were analyzed using Analysis of Variance (ANOVA). Treatments were compared using Honesty Square Design (HSD). The experimental field with an area of 337.5 square meter was thoroughly plowed and harrowed twice using a tractor to break the compacted soil, until the soil have obtained a fine tilth which is essential to achieve good germination. After preparing the land, the furrows were constructed by animal drawn implement. Three blocks were made with 50 centimeter spacing in between, and each block will be subdivided into six plots representing the treatments. Soybean seeds were planted on the field once the area was fully prepared. Planting was done manually by sowing three seeds per hill with a planting distance of $20 \mathrm{~cm} \mathrm{x} 75 \mathrm{~cm}$.

Power Organic, Urea, and Super Phosphate were have been used to supply the needed nutrient requirement of the crop. The amount of fertilizer applied to the soybean was based on the results of the soil analysis. The Power Organic was applied in the prescribed treatments a week after planting, while application of inorganic fertilizer was done 2 weeks after planting. The method of application used was side dressing.

The amount of fertilizer used are as follows: T1 - No fertilizer application, T2 - $500 \mathrm{~kg} / \mathrm{ha}$ of Power Organic,T3 - $21.74 \mathrm{~kg} / \mathrm{ha}$ of Urea and $150 \mathrm{~kg} / \mathrm{ha}$ of Super Phosphate, T4 - $250 \mathrm{~kg} / \mathrm{ha}$ of Power Organic $+10.87 \mathrm{~kg} / \mathrm{ha}$ of Urea and $75 \mathrm{~kg} / \mathrm{ha}$ of Super Phosphate, T5 - $375 \mathrm{~kg} / \mathrm{ha}$ of Power Organic $+5.44 \mathrm{~kg} / \mathrm{ha}$ of Urea and 37.5/ha of Super Phosphate, and T6 - $125 \mathrm{~kg} / \mathrm{ha}$ of Power Organic $+16.31 \mathrm{~kg} / \mathrm{ha}$ of Urea and $112 \mathrm{~kg} / \mathrm{ha}$ of Super Phosphate.

\subsection{Alkaline pretreatment}

\subsection{Anaerobic digestion $(A D)$ of common reed}

The capacity of the fermenter was 3 liters, $15 \%$ total solid (TS) of substrates were computed [10] as medium solids anaerobic digestion systems contain $15 \%-20 \%$. Thus, 375 grams were estimation for fermentation to match with 2.5 liters working volume. The solid states were a combination of cow dung and common reed in anaerobic co-digestion. Moreover, to investigate the productivity of substrates 3 ratios accompanied as 3 treatments (T): T1 (1:2), T2 (1:1), and T3 (2:1) each ratio with 3 replications. In other words, the ratio of common reed: cow dung was followed (by mass) as 125:250, 187.5:187.5, and 250:125 (grams). To reach 2.5 liters level 2 liters of distilled deionized water was added. Besides, control tests of both common reed and cow dung were implemented to compare the effectiveness of the system. 


\subsection{Experiment}

All experimental setups were run in triplicate, the fermenters were recapped by rubber stoppers, and gas outlet will go through equipped pipes with the valve to collect samples. Moreover, the bioreactors undergo ambient temperature during summertime with the range $26^{\circ} \mathrm{C}-40^{\circ} \mathrm{C}$ and shake by manual 3 times per day to ensure that the bacterial communities survival and decompose organic matter via the nutrient from the substrate in fermenters. The capacity of gasholders was 1 liter. Before fermentation happened all air (oxygen and other trace gases) would be taken out from pipes, gas holders, and fermenters by rubber aspirator to insure anaerobic condition Fig 2 . The gas produced was measured equivalent to the volume of water decreased from gasholders. Those experiments were run until generating of methane from system discontinue.

\subsection{Analytical methods}

All parameters in this study were conducted in triplicates and followed: TS (total solid), VS (volatile solids), moisture, volatile fatty acids (VFA), alkalinity (ALK), and chemical oxygen demand (COD) were detected according to the standard methods for the examination of water and wastewater (APHA, 2005). Ash content was measured according to AOAC official method 942.05. The $\mathrm{pH}$ value was tested by $\mathrm{pH}$ meter (Oakton PCSTestr 35 waterproof). Carbon and nitrogen contents of the material were determined by C-H-N-S-O analyzer (2400 II CHNS/O Elemental Analyzer, Perkin-Elmer, USA). The cellulose, hemicellulose, and lignin contents were determined and estimated base on a dry basis. The method was adopted by Ref. [14].

\section{RESULT AND DISCUSSION}

\subsection{Days to Flowering and Days to Maturity}

The number of days to $50 \%$ flowering showed significant results on the six treatments. The treatment $4(50 \%$ OF $+50 \%$ IF) flowered earlier than the other treatments at 34.6 days after planting. It was then followed by the T6, T2, T5 and T3 with a means of $35.5,36.4,36.7$ and 37.0 days (Table 1). The control seemed to have flowered late at 37.9 days after planting. As of the days to maturity, there was no significant difference observed among the treatments. Days to maturity was recorded when almost all the ten sample plants shows signs of maturity.

\subsection{Plant height at flowering, 60 days after planting, and at maturity}

Treatment $4(50 \% \mathrm{OF}+50 \% \mathrm{IF})$ and treatment $6(25 \% \mathrm{OF}+$ $75 \%$ IF) achieved the highest plant height at flowering stage with a mean of $53.2 \mathrm{~cm}$ and $50.73 \mathrm{~cm}$, but was found comparable to treatment 2 (100\% RR of OF), treatment 3 and treatment 4 with the means of $45.33 \mathrm{~cm}, 46.83 \mathrm{~cm}$, and $46.97 \mathrm{~cm}$. The treatment 1 (control) got the least height with a mean of $37.33 \mathrm{~cm}$ (Table 2). Analysis of data revealed that there was a significant difference among the treatment means. However, on the plant height at 60 days after planting, there was no significant difference noted. Regardless of the treatments, the height of the soybean plant ranges from $47.83 \mathrm{~cm}$ to $61.53 \mathrm{~cm}$.

Based on the data, the plant height at maturity got the same analysis with that of plant height at 60 days, and there was no significant difference among the treatments. The soybean height at 60 days ranges from $52.24 \mathrm{~cm}$ to $63.97 \mathrm{~cm}$.
Table 1. Days to flowering and maturity of soybean applied with organic and inorganic fertilizers

\begin{tabular}{|c|c|c|}
\hline \multirow{2}{*}{ TREATMENTS } & \multicolumn{2}{|c|}{ PARAMETERS } \\
\cline { 2 - 3 } & $\begin{array}{c}\text { DAYS TO } \\
\text { FLOWERING* }\end{array}$ & $\begin{array}{c}\text { DAYS TO } \\
\text { MATURITY }\end{array}$ \\
\hline T1 - Control & $37.9 \mathrm{a}$ & 78.5 \\
\hline T2 - 100\% RR of OF & $36.4 \mathrm{bc}$ & 78.3 \\
\hline T3 - 100\% RR of IF & $37.0 \mathrm{ab}$ & 79.0 \\
\hline $\begin{array}{c}\text { T4 - 50 \% OF + 50 \% } \\
\text { IF }\end{array}$ & $34.6 \mathrm{~d}$ & 77.9 \\
\hline $\begin{array}{c}\text { T5 - 75 \%F + 25\% } \\
\text { IF }\end{array}$ & $36.7 \mathrm{abc}$ & 78.4 \\
\hline $\begin{array}{c}\text { T6 - 25 OF + 75\% } \\
\text { IF }\end{array}$ & $35.5 \mathrm{~cd}$ & 77.9 \\
\hline
\end{tabular}

*Means with the same letter are not significantly different (HSD).

Table 2. Plant height at flowering, 60 days after planting, and at maturity of soybean applied with organic and inorganic fertilizers $(\mathrm{cm})$.

\begin{tabular}{|c|c|c|c|}
\hline \multirow{2}{*}{ TREATMENTS } & \multicolumn{3}{|c|}{ PARAMETERS } \\
\cline { 2 - 4 } & FLOWERING* & 60 DAP & $\begin{array}{c}\text { DAY OF } \\
\text { MATURITY }\end{array}$ \\
\hline T1 - Control & $37.33 \mathrm{~b}$ & 47.83 & 52.24 \\
\hline $\begin{array}{c}\text { T2 - 100 \% RR of } \\
\text { OF }\end{array}$ & $45.33 \mathrm{ab}$ & 54.67 & 58.47 \\
\hline $\begin{array}{c}\text { T3 - } 100 \% \text { RR of } \\
\text { IF }\end{array}$ & $46.83 \mathrm{ab}$ & 57.23 & 59.77 \\
\hline $\begin{array}{c}\text { T4 - 50 \%F + 50 } \\
\% \text { IF }\end{array}$ & $53.20 \mathrm{a}$ & 59.32 & 63.97 \\
\hline $\begin{array}{c}\text { T5 - 75 \% OF + 25 } \\
\% \text { IF }\end{array}$ & $46.97 \mathrm{ab}$ & 54.70 & 61.58 \\
\hline $\begin{array}{c}\text { T6 - 25 \% + }+75 \\
\% \text { IF }\end{array}$ & $50.73 \mathrm{a}$ & 61.53 & 61.58 \\
\hline
\end{tabular}

*Means with the same letter are not significantly different (HSD).

Table 3. Number of pods per plant, seeds per pod, length of pods $(\mathrm{cm})$, weight of 100 seeds $(\mathrm{g})$ and shelling percentage $(\%)$

\begin{tabular}{|l|c|c|c|c|c|}
\hline \multirow{2}{*}{ TREATMENTS } & \multicolumn{5}{|c|}{ PARAMETERS } \\
\cline { 2 - 6 } & $\begin{array}{c}\text { Number of } \\
\text { pods/plants }\end{array}$ & $\begin{array}{c}\text { Seed/ } \\
\text { pod }\end{array}$ & $\begin{array}{c}\text { Length } \\
\text { of pods } \\
(\mathrm{cm})\end{array}$ & $\begin{array}{c}\text { Weight } \\
\text { of } 100 \\
\text { seeds } \\
(\mathrm{g})\end{array}$ & $\begin{array}{c}\text { Shelli } \\
\text { ng } \\
\text { perce } \\
\text { ntage } \\
(\%)\end{array}$ \\
\hline T1 - Control & 31.10 & 2 & $3.16 \mathrm{~b}$ & $7.33 \mathrm{~b}$ & 53.08 \\
\hline $\begin{array}{l}\text { T2 - 100 \% RR } \\
\text { of IF }\end{array}$ & 43.27 & 3 & $3.53 \mathrm{ab}$ & $9.33 \mathrm{ab}$ & 51.55 \\
\hline $\begin{array}{l}\text { T3 - 100 \% RR } \\
\text { of IF }\end{array}$ & 44.00 & 3 & $3.58 \mathrm{ab}$ & $9.33 \mathrm{ab}$ & 52.59 \\
\hline $\begin{array}{l}\text { T4 - 50 \% OF + } \\
50 \% \text { IF }\end{array}$ & 47.39 & 3 & $3.84 \mathrm{a}$ & $11.00 \mathrm{a}$ & 50.45 \\
\hline $\begin{array}{l}\text { T5 - 75 \% OF + } \\
25 \% \text { IF }\end{array}$ & 45.03 & 3 & $3.71 \mathrm{a}$ & $9.33 \mathrm{ab}$ & 53.55 \\
\hline $\begin{array}{l}\text { T6 - 25 \% OF + } \\
75 \% \text { IF }\end{array}$ & 57.20 & 3 & $3.80 \mathrm{a}$ & $9.00 \mathrm{ab}$ & 53.58 \\
\hline
\end{tabular}

*Means with the same letter are not significantly different (HSD).

\subsection{Number of Pods}

Table 3 shows the number of pods per plant, seeds per pod, length of pods $(\mathrm{cm})$, weight of 100 seeds $(\mathrm{g})$ and shelling percentage $(\%)$ Number of pods per plant. This was obtained by counting the number of pods of the ten randomly selected sample plants and get the average. 


\subsection{Computed seed yield per hectare.}

The seed yield from the area planted was weighed and converted to a hectare basis. Computed yield of treatments is shown in Table 4.

Table 4. Computed yields of soybean applied with organic and inorganic fertilizers

\begin{tabular}{|l|c|}
\hline Treatment & Computed yield (kg/ha) \\
\hline T1 - Control & $460.27 \mathrm{~b}$ \\
\hline T2 - 100\% RR of OF & $542.96 \mathrm{ab}$ \\
\hline $\mathrm{T} 3-100 \%$ RR of IF & $560.62 \mathrm{ab}$ \\
\hline $\mathrm{T} 4-50 \%$ OF + 50\% IF & $771.05 \mathrm{a}$ \\
\hline $\mathrm{T} 5-75 \% \mathrm{OF}+25 \% \mathrm{IF}$ & $611.97 \mathrm{ab}$ \\
\hline $\mathrm{T} 6-25 \% \mathrm{OF}+75 \% \mathrm{IF}$ & $766.73 \mathrm{a}$ \\
\hline
\end{tabular}

*Means with the same letter are not significantly different (HSD).

\subsection{Cost and return analysis}

The cost and return analysis was determined by computing all the operational like inputs used in the experiment (Table 5). This was obtained using the formula:

Return of Investment $=$ Net income $\times 100 \%$ Total cost of production

Treatment $4(50 \% \mathrm{OF}+50 \% \mathrm{IF})$ and treatment $6(25 \% \mathrm{OF}+75 \%$ IF) achieved the highest ROI with a mean of $32.64 \%$ and $82.12 \%$, The treatment T3 and T1 (control) got the least ROI with a mean of $27.92 \%$ and 42.64 respectively (Table 5).

Table 5. Cost and Return of Investment of soybean applied with organic and inorganic fertilizers

\begin{tabular}{|c|c|c|c|c|c|c|}
\hline Particulars & $\begin{array}{c}\mathrm{T} 1 \\
\text { Control }\end{array}$ & $\begin{array}{c}\mathrm{T} 2 \\
100 \% \mathrm{RR} \text { of } \\
\mathrm{OF}\end{array}$ & $\begin{array}{c}\text { T3 } \\
100 \% \text { RR of OF }\end{array}$ & $\begin{array}{c}\mathrm{T} 4 \\
50 \% \mathrm{OF}+50 \\
\% \mathrm{IF}\end{array}$ & $\begin{array}{c}\mathrm{T} 5 \\
75 \% \mathrm{OF}+25 \% \\
\text { IF }\end{array}$ & $\begin{array}{c}\mathrm{T} 6 \\
25 \% \mathrm{OF}+75 \% \mathrm{IF}\end{array}$ \\
\hline $\begin{array}{l}\text { Gross income (computed } \\
\text { yield x farm gate price of } \\
90 \mathrm{~kg} \text { ) }\end{array}$ & $\begin{array}{c}41,424.3(460.27 \\
\mathrm{kg} / \mathrm{ha})\end{array}$ & $\begin{array}{c}48,866.4 \\
(542.96 \mathrm{~kg} / \mathrm{ha})\end{array}$ & $\begin{array}{c}50,455.8(560.62 \\
\mathrm{kg} / \mathrm{ha})\end{array}$ & $\begin{array}{c}69,394.5 \\
(771.05 \mathrm{~kg} / \mathrm{ha})\end{array}$ & $\begin{array}{c}55,077.3(611.97 \\
\mathrm{kg} / \mathrm{ha})\end{array}$ & $\begin{array}{c}69,005.7(766.73 \\
\mathrm{kg} / \mathrm{ha})\end{array}$ \\
\hline Total cost & $31,230.00$ & $33,230.00$ & $39,443.06$ & $36,336.53$ & $34,783.30$ & $37,889.80$ \\
\hline Net income & $10,194.30$ & $15,636.4$ & $11,012.74$ & $33,057.97$ & $20,294.00$ & $31,115.90$ \\
\hline ROI & $32.64 \%$ & $47.06 \%$ & $27.92 \%$ & $90.98 \%$ & $58.34 \%$ & $82.12 \%$ \\
\hline
\end{tabular}

\section{Conclusion}

On the basis of the results gathered in this experiment, following conclusion can be drawn:

1) The plants treated with $50 \%$ Organic Fertilizer $+50 \%$ Urea and Super Phosphate significantly flowered earlier compared to other treatments.

2) Days to maturity revealed significant findings among the treated plants.

3) In terms of plant height at flowering, the treatment with 50 $\%+50 \%$ and $25 \%+75 \%$ organic and inorganic fertilizers, significantly got the highest height among other treatments, but it is found comparable to treatment 2,3 , and 5 . On the other hand, insignificant results was noted on the six treatments in terms of plant height at 60 days and at maturity

4) Insignificant results was observed on soybean applied with organic and inorganic fertilizers on the parameters number of pods per plant and number of seeds per pod. When it comes to length of pods, the treatments applied with organic and inorganic fertilizer with different levels of combination was found significantly lengthening the pods.

5) Application of $50 \%$ organic and $50 \%$ inorganic fertilizer significantly obtained the heaviest weight of 100 seeds. It was observed from the data that it was comparable to $\mathrm{T} 2, \mathrm{~T} 3$, $\mathrm{T} 4$ and $\mathrm{T} 6$.
6) Plants treated with organic and inorganic fertilizers did not vary significantly in terms of shelling percentage.

7) Among the organic and inorganic combinations, the treatment 4 treated with $50 \%$ Power Organic $+50 \%$ Urea and Super Phosphate and the plants applied with $75 \%$ Power Organic $+25 \%$ Urea and Super Phosphate was found superior in recording the computed seed yield per hectare. 8 . The combination of $50 \%$ Power Organic $+50 \%$ Urea and Super Phosphate (T4) was found valuable for achieving higher net monetary returns.

8) The results of the study testifies that combined use of organic and inorganic sources of fertilizer can give a better performance on soybean production.

\section{Reference}

[1] Encyclopedia of Food and Culture. 2003. Legumes. Retrieved on November 2017 from http://www.encyclop edia.com/plants-and-animals/plants/plants/legume.

[2] Encyclopædia Britannica. 2017. Soybean Plant. Retrieved from https://www.britannica.com/plant/so ybean on November 2017

[3] Enicola, E. 2008. Soybean in the Philippines. Retrieved on $\quad$ November 2017 from https://philsoybeans.Blogspot.com/2009/ 10/soybean-inphilippines.html\#more

[4] Chen, J. 2008. The Combined Use of Chemical and Organic Fertilizers and/or Biofertilizer for Crop Growth 
and Soil Fertility. Retrieved from http://www. fftc. agnet.org/library.php?func=view\&id=20110 808103954 on November 2017.

[5] Chand, S., Anwar, M. \& Patra, D.D. 2006. Influence of long-term application of organic and inorganic fertilizer to build up soil fertility and nutrient uptake in mintmustard cropping sequence. Communications in Soil Science and Plant Analysis, 37: 63-76.

[6] Jat, N. 2017. Effect of conjunctive use of organics on soybean crop under dryland farming. Department of Soil science and agricultural chemistry Rajmata Vijayaraje Scindia Krishi Vishwa Vidyalaya, Gwalior College of Agriculture, Indore (MP). Published thesis.

[7] Shirpukar, G.N., Kashid, N.V., Kamble, M.S., Pisal, A.A. and Sarode, N.D. 2006. Effect of application of Zn, B and Mo on the yield and yield attributing characters of soybean. Legume Res. 29 (4): 242-246.

[8] Bandyopadhyay, K.K., Misra, A.K., Ghosh, P.K., Hati, K.M., and Mandal, K.O. 2003. Effect of Integrated use of Farmyard Manure and Inorganic Fertilizers on Soil Water Dynamics, Root Growth, Crop Yield and Water Expense Efficiency of Rainfed Soybean in a Vertisol. Joltr. Agric. Physics, Vol. 1, No.1 \& 2, pp. 95-100
[9] Mahesh Babu, H.M., Ravi Hunje, Biradar Patil, N.K and Babalad, H.B. 2008.Effect of organic manures on plant growth, seed yield and quality of Soybean. Karnataka Journal of Agricultural science. 21(2): 219-221 .

[10] Yamika, W.S.D. and Ikawati, K.R. 2012. Combination inorganic and organic fertilizer increased yield production of soybean. American-Eurasian J. Sustainable Agric. 6(1): 14-17.

[11] Singh, M., Beura, K., Pradhan, A.K., and Kumar, N. 2015. Conjunctive organic and mineral fertilization - its role in nutrient uptake and yield of soybean under Mollisol ,The Boiscan- An International Quarterly Journal Of Life Science, 10 (3): 1275-1279.

[12] Khaim, S., Chowdhury A.H., and Saha, B.K. 2013. Organic and inorganic fertilization on the yield and quality of soybean. J. Bangladesh Agril. Univ. 11(1): 23 28

[13] Wolie, A.W. and Admassu, M.A. 2016. Effects of Integrated Nutrient Management on Rice (Oryzasativa L) Yield and Yield Attributes, Nutrient Uptake and Some Physico-Chemical Properties of Soil: A Review, Journal of Biology, Agriculture and Healthcare 6 (5).

[14] Vu PT, Y Unpaprom, R Ramaraj, 2018. Impact and significance of alkaline-oxidant pretreatment on the enzymaticdigestibility of Sphenoclea zeylanica for bioethanol production. Bioresource Technology 274: 125-130. 